\title{
Optimizing root system architecture in biofuel crops for sustainable energy production and soil carbon sequestration Jennifer PC To ${ }^{1}$, Jinming Zhu ${ }^{1}$, Philip N Benfey ${ }^{1,2}$ and Tedd Elich ${ }^{1 *}$
}

Addresses: ${ }^{1}$ GrassRoots Biotechnology, 302 E Pettigrew Street, Suite A200, Durham, NC 27701, USA; ${ }^{2}$ Department of Biology and IGSP Center for Systems Biology, Duke University, Durham, NC 27708, USA

*Corresponding author: Tedd Elich (tedd.elich@grassrootsbio.com)

Fl000 Biology Reports 2010, 2:65 (doi:10.3410/B2-65)

The electronic version of this article is the complete one and can be found at: http://fl000.com/reports/biology/content/2/65

Abstract
Root system architecture (RSA) describes the dynamic spatial configuration of different types and
ages of roots in a plant, which allows adaptation to different environments. Modifications in RSA
enhance agronomic traits in crops and have been implicated in soil organic carbon content. Together,
these fundamental properties of RSA contribute to the net carbon balance and overall sustainability of
biofuels. In this article, we will review recent data supporting carbon sequestration by biofuel crops,
highlight current progress in studying RSA, and discuss future opportunities for optimizing RSA for
biofuel production and soil carbon sequestration.

\section{Introduction and context}

Carbon dioxide $\left(\mathrm{CO}_{2}\right)$ is the major anthropogenic greenhouse gas (GHG) and its atmospheric concentration has risen by approximately 100 parts per million since the Industrial Revolution. With current $\mathrm{CO}_{2}$ accumulation rates, global temperatures are predicted to increase between $1.4^{\circ} \mathrm{C}$ and $5.8^{\circ} \mathrm{C}$ by the end of this century [1]. Fossil fuel consumption releases carbon (C) from underground stores into the atmosphere and is a major contributor to the increase of GHG. In contrast, biofuels can be considered C-neutral or C-negative because the majority of $\mathrm{C}$ emitted from their consumption is fixed from ambient $\mathrm{CO}_{2}$. However, estimates of GHG balances from biofuel crop production vary from $\mathrm{C}$-negative to C-positive depending on the assumptions, components, and boundaries used in the analysis [2]. The uncertainties that contribute to these variable estimates include GHG emissions from energy inputs during crop production and biofuel processing as well as terrestrial $\mathrm{C}$ loss due to converting land to agriculture. Furthermore, biofuel crop cultivation may raise land use issues, including competition with food production and destruction of natural habitats [3]. What is clear from these studies is that the sustainability of biofuels depends on the availability of feedstocks that can grow on low-quality soils like abandoned farmland, are productive with minimal energy inputs, and can potentially increase soil organic carbon (SOC) accumulation [4].

Root system architecture (RSA) describes the spatial configuration of different types and ages of roots in a plant. RSA is highly plastic and varies with growth conditions to allow soil exploration for nutrients; variation in RSA is found between species and between varieties within a species that are adapted to different environments [5]. In agricultural crops, RSA has been shown to enhance yield, drought tolerance, and nutrient efficiency, which can increase productivity and reduce input requirements [6-9]. For optimal growth on marginal lands, biofuel crop RSA should promote shallow adventitious roots and dispersed lateral roots to forage topsoils for diffusion-limited nutrients and reduce runoff on steep grades as well as deeper roots to increase water and soluble nutrient uptake [9]. Furthermore, root tissue and exudates contribute to terrestrial C pools. Increasing root biomass, in particular with deeper roots, has been predicted to increase $\mathrm{C}$ sequestration 
because $\mathrm{C}$ loss due to microbial decomposition is concentrated in the upper soil strata [10].

Herbaceous perennial grasses such as switchgrass and Miscanthus can grow on marginal lands, efficiently fix C, and reduce net $\mathrm{CO}_{2}$ emissions through $\mathrm{C}$ sequestration in deep roots [11]. Low-input, high-diversity perennial grasses grown for biofuels have been estimated to sequester 4.85 tons/hectare per year of $\mathrm{CO}_{2}$, while current corn grain ethanol and soybean diesel are C-positive $[12,13]$. Despite these attributes, perennial grasses have not been widely adopted commercially because cellulosic ethanol is not cost-competitive with fossil fuels in the current market $[14,15]$. Increasing the agronomic productivity and environmental benefits of biofuel crops by modifying RSA can facilitate the entry of biofuels into the marketplace.

\section{Major recent advances}

\section{Changes in soil organic carbon under biofuel crops}

A large-scale switchgrass field study recently reported net energy gains of cellulosic ethanol and increase in SOC $[16,17]$. This study was conducted on 10 farms averaging 6.7 hectares across a 930-km latitude range in the central and northern Great Plains in the US. SOC underwent significant increases: 4.0 megagrams of $\mathrm{CO}_{2} /$ hectare per year at a soil depth of $0-30 \mathrm{~cm}$ and 10.6 megagrams of $\mathrm{CO}_{2} /$ hectare per year at a soil depth of $0-120 \mathrm{~cm}$ [17]. Another recent study re-analyzed changes in soil organic $\mathrm{C}$ under biofuel feedstock cultivation across a set of 46 experiments representing 146 site treatment combinations [18]. These experiments tested four types of biofuel feedstocks (corn stover, sugarcane, Miscanthus, and switchgrass) and mixed native prairie grasses. All feedstocks, except corn stover, were correlated with an increase in SOC. Notably, Miscanthus and switchgrass were estimated to increase SOC by $5-25 \%$ at a soil depth of $0-60 \mathrm{~cm}$ in 5-20 years. Sugarcane plots were found to accumulate SOC in smaller amounts and at shallower depths than switchgrass. Mixed native grasses that were not harvested for biofuel production were predicted to have the highest potential to accumulate SOC [18]. The results were complicated by the effects of site soil characteristics, management practices, and climate. Nonetheless, the results were generally consistent with predictions that SOC would decrease as a result of conversion of native ecosystems to agricultural use, and that SOC would accumulate as a result of conversion of farmland to grassland. [19]. Globally, there are approximately 400 megahectares of abandoned farmland that have not been converted to other uses [20]. Cultivating perennial grasses on this land for energy crop production is projected to sequester up to 1.9 gigatons/year of $\mathrm{CO}_{2}$.

\section{Phenotyping and optimizing root system architecture in biofuel crops}

Functional RSA traits for biofuel feedstocks, including increased root depth and branching, are proposed to increase productivity on marginal land and promote C sequestration $[9,10]$. These root traits have been referred to as traits of the second Green Revolution because they enhance crop tolerance to drought and lownutrient conditions that are prevalent in the developing world [9]. Unfortunately, owing to high-input conditions used during selection as well as the difficulty of observing underground tissues, these traits have often been neglected in traditional programs for breeding. Recent implementation of noninvasive in vivo root imaging systems such as gel-based optical imaging [21], X-ray imaging [22], nuclear magnetic resonance [23], and short-lived radioisotope imaging [24] is expediting efforts to characterize RSA traits. Further advances in automating image capture and analysis methods have been reported in Arabidopsis and rice $[21,25]$ and will facilitate genome-wide identification of RSA traits in biofuel crops.

While recent studies support perennial grasses for efficient soil C sequestration [16-18], they also raise the issue of a trade-off in $\mathrm{C}$ allocations aboveground and belowground, which contribute to biofuel crop productivity and SOC accumulation, respectively $[18,26]$. In addition, SOC has been correlated with levels of nitrogen $[19,27]$, likely in part through modulation of plant $\mathrm{C}$ cycles and RSA. Efforts to optimize RSA for nitrogen uptake efficiency can potentially increase $C$ sequestration capabilities. Understanding how plants respond to $\mathrm{C}$ and nitrogen inputs in variable environments and how these inputs are allocated into shoot biomass aboveground for harvest and root biomass belowground for $\mathrm{C}$ sequestration are interesting research areas for biofuel crop improvement.

\section{Genetic control of root system architecture in grasses}

Studies on genetic determinants of RSA have been pursued largely in the model dicot Arabidopsis as well as in the cereals rice and maize (reviewed in [28-31]). In Arabidopsis, RSA is defined by iterative development of lateral roots beginning on the radicle-derived primary root. Arabidopsis lateral root development, from initiation through patterning events after emergence, is coordinated largely by the phytohormones auxin and cytokinin $[29,30,32]$. Elongation of primary and lateral roots is mediated by both cell division and cell expansion control, including cell wall biosynthesis and modification mechanisms [30,33]. Adaptive RSA results from lateral root development and directional root elongation responses to environmental signals such as nutrient 
levels and mechanical stimuli, which are modulated in part by phytohormones [34,35]. Rice, maize, and other monocots generate a more complex fibrous root system that includes embryonic primary and seminal roots, postembryonic soil-borne or air-borne adventitious roots, and lateral roots that arise from all of the aforementioned types. Recent cloning of a number of genes mutated in rice and maize root branching-defective mutants has identified genes involved in polarized auxin transport and response and identified cytokinin response pathways [29,30] and transcription factors, including auxin-inducible LATERAL ORGAN BOUNDARY transcription factors in maize [36] and rice [37] and a cytokinin-regulated WUSCHEL-related homeobox gene in rice [38]. These findings suggest that conservation in root branching mechanisms between monocots and dicots persists despite major differences in RSA and lend support to comparative genomic approaches.

In perennial grasses, the study of RSA genes is in its infancy and this is primarily due to their large and complex genomes. Recently, genome sequencing of the cultivated grass Sorghum bicolor [39] and the wild grass Brachypodium dystachion [40] has been completed, and genome sequencing of proposed biofuel feedstocks foxtail millet and switchgrass is under way. Comparative genomics has identified homologs and regions of synteny between these grasses [40-43], and these regions will facilitate identification of orthologous gene sets involved in RSA in biofuel crops.

A recent major breakthrough in Arabidopsis root development was the identification of microRNAs (miRNAs) that regulate lateral root branching and root patterning [44-46]. Genomic approaches have identified miRNAs in maize [47-49], rice [50], Brachypodium [51,52], and switchgrass [53]. Artificial miRNAs have been used to modulate gene expression in many experimental systems [54], and understanding miRNAs in grasses can potentially develop this tool for manipulating RSA in biofuel crops.

Global transcriptional profiling experiments using microarrays have identified rice genes responsive to environmental changes in nitrogen and water stress conditions [55,56]. A high-resolution transcriptional map of the rice root and gene expression profiles of several maize root cell types (wild-type and mutant) that regulate root branching have been generated by means of laser capture microdissection $[57,58]$. Comparison of these gene expression profiles with high-resolution gene expression profiles generated from Arabidopsis [59] implicates sets of common and distinct genetic mechanisms in RSA determination.
Quantitative trait loci (QTLs) mapping in rice and maize is ongoing, and many QTLs controlling root traits in rice and maize have been identified but none has yet been cloned $[6,28,29]$. The gene expression data will also inform RSA candidate gene prioritization in QTLs in the future. Genetic tools in biofuel crops, including germplasms of natural accessions, recombinant- and near-inbred line populations, mutants, and genetic and physical maps as well as genetic transformation methods, are being developed to advance trait identification in biofuel crops [60-63].

\section{Future directions}

Genetic tools, as mentioned above, including germplasms of natural accessions and mutants as well as genetic and physical maps of biofuel crops, are currently being developed. These tools, coupled with large-scale phenotyping and genotyping pipelines, will expedite discovery of RSA traits and genes for breeding and genetic manipulation to generate improved C-negative biofuel crops with sustainable biomass production.

\section{Abbreviations}

$\mathrm{C}$, carbon; $\mathrm{CO}_{2}$, carbon dioxide; $\mathrm{GHG}$, greenhouse gas; miRNA, microRNA; QTL, quantitative trait locus; RSA, root system architecture; SOC, soil organic carbon.

\section{Competing interests}

GrassRoots Biotechnology is a for-profit organization that conducts research to enhance agricultural and biofuel crops. We apologize to any colleagues whose work was excluded because of space constraints.

\section{Acknowledgments}

Research at GrassRoots Biotechnology on improving root architecture in energy crops is funded by grant 200933610-19670 from the US Department of Agriculture Small Business Innovation Research Program.

\section{References}

I. Intergovernmental Panel on Climate Change: Climate Change 2007: The Physical Science Basis. Cambridge, UK, and New York, NY, USA: Cambridge University Press; 2007.

2. Davis SC, Anderson-Teixeira KJ, Delucia EH: Life-cycle analysis and the ecology of biofuels. Trends Plant Sci 2009, I4:|40-6.

3. Fargione J, Polasky S, Hawthorne P, Hill J, Tilman D: Land clearing and the biofuel carbon debt. Science 2008, 3 | 9: | 235-8.

FI000 Factor 9.0 Exceptional

Evaluated by Andrew Hector 25 Feb 2008

4. Blanco-Canqui H: Energy crops and their implications on soil and environment. Agron J 2010, 102:403-17.

5. Fitter A: Plant roots: the hidden half. In Books in Soils, Plants, and the Environment. 3rd edition. Edited by Waisel Y, Eshel A, Kafkafi U. New York: Marcel Dekker; 2002:15-32. 
6. de Dorlodot $S$, Forster $B$, Pagès $L$, Price $A$, Tuberosa R, Draye X: Root system architecture: opportunities and constraints for genetic improvement of crops. Trends Plant Sci 2007, I 2:474-8I.

7. Hammer GL, Doug Z, McLean G, Doherty A, Messina C, Schussler J, Zinselmeier C, Paszkiewicz S, Cooper M: Can changes in canopy and/or root system architecture explain historical maize yield trends in the U.S. corn belt? Crop Sci 2009, 49:299-3I2.

8. Hirel B, Le Gouis J, Ney B, Gallais A: The challenge of improving nitrogen use efficiency in crop plants: towards a more central role for genetic variability and quantitative genetics within integrated approaches. J Exp Bot 2007, 58:2369-87.

9. Lynch JP: Roots of the second Green Revolution. Aust J Bot 2007, 55:493-5। 2

10. De Deyn GB, Cornelissen JHC, Bardgett RD: Plant functional traits and soil carbon sequestration in contrasting biomes. Ecol Lett 2008, II:516-31.

II. Robertson GP, Dale VH, Doering OC, Hamburg SP, Melillo JM, Wander MM, Parton WJ, Adler PR, Barney JN, Cruse RM, Duke CS, Fearnside PM, Follett RF, Gibbs HK, Goldemberg J, Mladenoff DJ, Ojima D, Palmer MW, Sharpley A, Wallace L, Weathers KC, Wiens JA, Wilhelm WW: Agriculture: sustainable biofuels redux. Science 2008, 322:49-50.

12. Tilman D, Hill J, Lehman C: Carbon-negative biofuels from lowinput high-diversity grassland biomass. Science 2006, 31 4: I598600.

\section{FI000 Factor 8.3 Exceptional}

Evaluated by Evan DeLucia 10 Jan 2007, Joy Ward II Jan 2007,

J Emmett Duffy 17 Jan 2007, Andrew Hector 20 Feb 2007, Wall 28 Mar 2007

13. Hill J, Nelson E, Tilman D, Polasky S, Tiffany D: Environmental, economic, and energetic costs and benefits of biodiesel and ethanol biofuels. Proc Natl Acad Sci U S A 2006, I 03:I I 206-I0.

FI000 Factor 6.0 Must Read

Evaluated by Paul Ehrlich 2I Dec 2006

14. Huang H-J, Ramaswamy S, Al-Dajani W, Tschirner U, Cairncross RA: Effect of biomass species and plant size on cellulosic ethanol: a comparative process and economic analysis. Biomass Bioenergy 2009, 33:234-46.

15. James LK, Swinton SM, Thelen KD: Profitability analysis of cellulosic energy crops compared with corn. Agron J 2010, I02:675-87.

16. Schmer MR, Vogel KP, Mitchell RB, Perrin RK: Net energy of cellulosic ethanol from switchgrass. Proc Natl Acad Sci U S A 2008, 105:464-9.

17. Liebig MA, Schmer MR, Vogel KP, Mitchell RB: Soil carbon storage by switchgrass grown for bioenergy. Bioenergy Res 2008, 1:2 I 5-22.

18. Anderson-Teixeira KJ, Davis SC, Masters MD, Delucia EH: Changes in soil organic carbon under biofuel crops. Glob Change Biol Bioenergy 2009, 1:75-96.

19. Govaerts B, Verhulst N, Castellanos-Navarrete A, Sayre KD, Dixon J, Dendooven L: Conservation agriculture and soil carbon sequestration: between myth and farmer reality. CRC Crit Rev Plant Sci 2009, 28:97-I22.

20. Field CB, Campbell JE, Lobell DB: Biomass energy: the scale of the potential resource. Trends Ecol Evol 2008, 23:65-72.

21. lyer-Pascuzzi AS, Symonova O, Mileyko Y, Hao Y, Belcher H, Harer J, Weitz JS, Benfey PN: Imaging and analysis platform for automatic phenotyping and trait ranking of plant root systems. Plant Physiol 2010, 152:1 148-57.

22. Perret JS, Al-Belushi ME, Deadman M: Non-destructive visualization and quantification of roots using computed tomography. Soil Biol Biochem 2007, 39:391-9.

23. Jahnke S, Menzel MI, van Dusschoten D, Roeb GW, Buhler J, Minwuyelet S, Blumler P, Temperton VM, Hombach T, Streun M, Beer S, Khodaverdi M, Ziemons K, Coenen HH, Schurr U: Combined MRI-PET dissects dynamic changes in plant structures and functions. Plant J 2009, 59:634-44.
24. Thorpe M, Ferrieri A, Herth M, Ferrieri R: I IC-imaging: methyl jasmonate moves in both phloem and xylem, promotes transport of jasmonate, and of photoassimilate even after proton transport is decoupled. Planta 2007, 226:54I-5I.

25. Durham Brooks TL, Miller ND, Spalding EP: Plasticity of Arabidopsis root gravitropism throughout a multidimensional condition space quantified by automated image analysis. Plant Physiol 2010, I52:206-16.

26. Laungani $\mathrm{R}, \mathrm{Knops} \mathrm{JMH}$ : The impact of co-occurring tree and grassland species on carbon sequestration and potential biofuel production. Glob Change Biol Bioenergy 2009, I:392-403.

27. Christopher SF, Lal R: Nitrogen management affects carbon sequestration in North American cropland soils. CRC Crit Rev Plant Sci 2007, 26:45-64.

28. Hochholdinger F, Tuberosa R: Genetic and genomic dissection of maize root development and architecture. Curr Opin Plant Biol 2009, 12: 172-7.

29. Coudert Y, Perin C, Courtois B, Khong NG, Gantet P: Genetic control of root development in rice, the model cereal. Trends Plant Sci 2010, 15:219-26.

30. Péret B, De Rybel B, Casimiro I, Benková E, Swarup R, Laplaze L, Beeckman T, Bennett MJ: Arabidopsis lateral root development: an emerging story. Trends Plant Sci 2009, 14:399-408.

31. lyer-Pascuzzi A, Simpson J, Herrera-Estrella L, Benfey PN: Functional genomics of root growth and development in Arabidopsis. Curr Opin Plant Biol 2009, 12:165-71.

32. Moubayidin L, Di Mambro R, Sabatini S: Cytokinin-auxin crosstalk. Trends Plant Sci 2009, 14:557-62.

33. Dolan L, Davies J: Cell expansion in roots. Curr Opin Plant Biol 2004, 7:33-9.

34. Richter GL, Monshausen GB, Krol A, Gilroy S: Mechanical stimuli modulate lateral root organogenesis. Plant Physiol 2009, 15 I: 1855-66.

35. Forde BG, Walch-Liu P: Nitrate and glutamate as environmental cues for behavioural responses in plant roots. Plant Cell Environ 2009, 32:682-93.

36. Taramino G, Sauer M, Stauffer JL Jr, Multani D, Niu X, Sakai H, Hochholdinger F: The maize (Zea mays L.) RTCS gene encodes a LOB domain protein that is a key regulator of embryonic seminal and post-embryonic shoot-borne root initiation. Plant J 2007, 50:649-59.

37. Inukai $\mathrm{Y}$, Sakamoto $\mathrm{T}$, Ueguchi-Tanaka M, Shibata $\mathrm{Y}$, Gomi K, Umemura I, Hasegawa Y, Ashikari M, Kitano H, Matsuoka M: Crown rootless I, which is essential for crown root formation in rice, is a target of an AUXIN RESPONSE FACTOR in auxin signaling. Plant Cell 2005, 17:1387-96.

FI000 Factor 6.4 Must Read

Evaluated by Christian Hardtke 27 May 2005, Yasounori Machida 24 Jun 2005

38. Zhao Y, Hu Y, Dai M, Huang L, Zhou DX: The WUSCHEL-related homeobox gene WOXII is required to activate shoot-borne crown root development in rice. Plant Cell 2009, 21:736-48.

39. Paterson $\mathrm{AH}$, Bowers JE, Bruggmann R, Dubchak I, Grimwood J, Gundlach H, Haberer G, Hellsten U, Mitros T, Poliakov A, Schmutz J, Spannagl M, Tang H, Wang X, Wicker T, Bharti AK, Chapman J, Feltus FA, Gowik U, Grigoriev IV, Lyons E, Maher CA, Martis M, Narechania A, Otillar RP, Penning BW, Salamov AA, Wang Y, Zhang L, Carpita NC, et al.: The Sorghum bicolor genome and the diversification of grasses. Nature 2009, 457:551-6.

40. International Brachypodium Initiative: Genome sequencing and analysis of the model grass Brachypodium distachyon. Nature 2010, 463:763-8.

4I. Kumar S, Mohan A, Balyan HS, Gupta PK: Orthology between genomes of Brachypodium, wheat and rice. BMC Res Notes 2009, 2:93.

42. Huo N, Vogel JP, Lazo GR, You FM, Ma Y, McMahon S, Dvorak J, Anderson OD, Luo MC, Gu YQ: Structural characterization of 
Brachypodium genome and its syntenic relationship with rice and wheat. Plant Mol Biol 2009, 70:47-6I.

43. Yilmaz A, Nishiyama MY Jr, Fuentes BG, Souza GM, Janies D, Gray J, Grotewold E: GRASSIUS: a platform for comparative regulatory genomics across the grasses. Plant Physiol 2009, I49: I7 I-80.

44. Guo HS, Xie Q, Fei JF, Chua NH: MicroRNA directs mRNA cleavage of the transcription factor NACI to downregulate auxin signals for Arabidopsis lateral root development. Plant Cell 2005, I 7:1376-86.

FI000 Factor 3.0 Recommended Evaluated by Tai-ping Sun 21 Apr 2005

45. Carlsbecker A, Lee JY, Roberts CJ, Dettmer J, Lehesranta S, Zhou J, Lindgren O, Moreno-Risueno MA, Vatén A, Thitamadee S, Campilho A, Sebastian J, Bowman JL, Helariutta Y, Benfey PN: Cell signalling by microRNAI65/6 directs gene dose-dependent root cell fate. Nature 2010, 465:316-21.

FI000 Factor 9.0 Exceptional

Evaluated by Niko Geldner 06 May 2010

46. Marin E, Jouannet V, Herz A, Lokerse AS, Weijers D, Vaucheret $H$, Nussaume L, Crespi MD, Maizel A: miR390, Arabidopsis TAS3 tasiRNAs, and their AUXIN RESPONSE FACTOR targets define an autoregulatory network quantitatively regulating lateral root growth. Plant Cell 2010, 22:I I04-I7.

FI000 Factor 6.0 Must Read

Evaluated by Jiri Friml I5 Apr 2010

47. Ding D, Zhang L, Wang H, Liu Z, Zhang Z, Zheng Y: Differential expression of miRNAs in response to salt stress in maize roots. Ann Bot 2009, I03:29-38.

48. Zhang Z, Wei L, Zou X, Tao Y, Liu Z, Zheng Y: Submergenceresponsive MicroRNAs are potentially involved in the regulation of morphological and metabolic adaptations in maize root cells. Ann Bot 2008, 102:509-19.

49. Zhang L, Chia JM, Kumari S, Stein JC, Liu Z, Narechania A, Maher CA, Guill K, McMullen MD, Ware D: A genome-wide characterization of microRNA genes in maize. PLoS Genet 2009, 5:e I0007I6.

50. Li YF, Zheng Y, Addo-Quaye C, Zhang L, Saini A, Jagadeeswaran G, Axtell MJ, Zhang W, Sunkar R: Transcriptome-wide identification of microRNA targets in rice. Plant J 2010, 62:742-59.

5I. Zhang J, Xu Y, Huan $Q$, Chong $K$ : Deep sequencing of Brachypodium small RNAs at the global genome level identifies microRNAs involved in cold stress response. BMC Genomics 2009, 10:449.

52. Unver $\mathrm{T}$, Budak $\mathrm{H}$ : Conserved microRNAs and their targets in model grass species Brachypodium distachyon. Planta 2009, 230:659-69.
53. Xie F, Frazier T, Zhang B: Identification and characterization of microRNAs and their targets in the bioenergy plant switchgrass (Panicum virgatum). Planta 2010, 232:4I7-34.

54. Stephan O, Rebecca S, Detlef W: Gene silencing in plants using artificial microRNAs and other small RNAs. Plant J 2008, 53:674-90.

55. Lian X, Wang S, Zhang J, Feng Q, Zhang L, Fan D, Li X, Yuan D, Han B, Zhang Q: Expression profiles of 10,422 genes at early stage of low nitrogen stress in rice assayed using a cDNA microarray. Plant Mol Biol 2006, 60:617-31.

56. Spollen WG, Tao W, Valliyodan B, Chen K, Hejlek LG, Kim JJ, Lenoble ME, Zhu J, Bohnert HJ, Henderson D, Schachtman DP, Davis GE, Springer GK, Sharp RE, Nguyen HT: Spatial distribution of transcript changes in the maize primary root elongation zone at low water potential. BMC Plant Biol 2008, 8:32.

57. Woll K, Borsuk LA, Stransky H, Nettleton D, Schnable PS, Hochholdinger F: Isolation, characterization, and pericyclespecific transcriptome analyses of the novel maize lateral and seminal root initiation mutant ruml. Plant Physiol 2005, |39:|255-67.

58. Dembinsky D, Woll K, Saleem M, Liu Y, Fu Y, Borsuk LA, Lamkemeyer T, Fladerer C, Madlung J, Barbazuk B, Nordheim A, Nettleton D, Schnable PS, Hochholdinger F: Transcriptomic and proteomic analyses of pericycle cells of the maize primary root. Plant Physiol 2007, I 45:575-88.

59. Brady SM, Orlando DA, Lee JY, Wang JY, Koch J, Dinneny JR, Mace D, Ohler U, Benfey PN: A high-resolution root spatiotemporal map reveals dominant expression patterns. Science 2007. 3 | 8:80|-6.

FI000 Factor 4.8 Must Read

Evaluated by Patrick Masson 07 Nov 2007, Elena Alvarez-Buylla 25 Feb 2008

60. Bevan MW, Garvin DF, Vogel JP: Brachypodium distachyon genomics for sustainable food and fuel production. Curr Opin Biotechnol 2010, 21:211-7.

61. Okada M, Lanzatella C, Saha MC, Bouton J, Wu R, Tobias CM: Complete switchgrass genetic maps reveal subgenome collinearity, preferential pairing, and multilocus interactions. Genetics 2010, I 85:745-60.

62. Xi Y, Ge Y, Wang ZY: Genetic transformation of switchgrass. Methods Mol Biol 2009, 58I:53-9.

63. Paterson AH: Genomics of sorghum. Int J Plant Genomics 2008, 2008:36245।. 